\title{
Mineraçãão
}

\section{Lead recovery by flotation with sodium lauryl sulfate}

\author{
Recuperação de chumbo por flotação \\ com sulfato lauril de sódio
}

\author{
Alessandra Gorette de Morais \\ Engenheira Civil, \\ Mestrado em Engenharia Mineral, UFPE. \\ ales_gm@yahoo.com.br

\section{Carlos Adolpho Magalhães Baltar \\ D.Sc., Professor Associado do Departamento \\ de Engenharia de Minas, UFPE \\ UFPE/CTG/DEMINAS. \\ camb@ufpe.br}

\section{Carlos Alberto Pereira}

D.Sc., Professor Associado do Departamento de Engenharia de Minas, UFOP

pereira@demin.ufop.br

\section{Resumo}

$\mathrm{O}$ processo metalúrgico para reciclagem de chumbo, a partir de baterias automotivas usadas, gera uma escória constituída, basicamente, por ferro e chumbo. A recuperação do chumbo contido nesse material descartado é de grande interesse econômico e ambiental. $\mathrm{O}$ trabalho teve, como objetivo, estudar a possibilidade de recuperar o chumbo através de flotação com sulfato lauril de sódio (SLS). A fim de se verificarem as condições mais favoráveis para a seletividade, procurou-se identificar o mecanismo de adsorção do SLS, nas partículas de chumbo e de ferro. A adsorção foi monitorada por meio de determinações de potencial zeta e tensão superficial. Foram realizados testes de flotação nas condições identificadas como mais promissoras para a seletividade. Os resultados sugerem que o SLS adsorve-se, quimicamente, à superfície das partículas de chumbo. $\mathrm{O}$ aumento do $\mathrm{pH}$ favorece a adsorção, possibilitando uma recuperação de $79 \%$ do chumbo contido com apenas $10^{-3} \mathrm{M}$ do coletor. No entanto, as condições mais favoráveis à seletividade foram observadas em meio ácido.

Palavras-chave: Flotação, flotação de escória, sulfato lauril de sódio, chumbo secundário, reciclagem de resíduo industrial.

\section{Abstract \\ Lead recoverable slag is of economic and environmental importance. The aim of this study was to assess the possibilities of its recovery by flotation with sodium lauryl sulfate (SLS). The similar nature of the lead and iron particles formed by solidification of the melted slag impairs selectivity during the flotation process. In order to verify the most favorable conditions for selectivity, SLS adsorption mechanisms for lead and iron particles were studied. The adsorption was monitored by means of zeta potential and surface tension determinations. Flotation tests were conducted under the most promising conditions identified for selectivity. The results suggest that SLS adsorption in lead particles is of a chemical nature. It was observed that the formation of lead lauryl sulfate is easier in alkaline medium. A 79\% lead recovery was obtained at pH 10 using only 10-3 M collector concentration. Nevertheless, the best selectivity conditions were obtained in an acid medium.}

Keywords: Flotation, metallurgical slag flotation, sodium lauryl sulfate, secondary lead, recycling of industrial waste. 


\section{Introduction}

Brazil has only about $0.11 \%$ of the world's metal reserves. In 2010, its production of primary lead concentrates reached a total of only 12,000 tons. This production comes from a single company, Companhia Mineira de Metais, in Paracatu, MG, pertaining to the Votorantim Group. This same year, the secondary lead, obtained mainly from recycling automotive batteries and telecommunication material, had an estimated production of 114,887 tons (Teixeira and
Silva, 2011).

Considering that Brazilian lead reserves are insufficient to meet the domestic demand, that the price of the metal in the international market continues to show a rising trend, and that waste containing lead represents a constant risk to human health and environmental contamination, the interest in obtaining secondary lead by recycling metal grows every day.

Part of the lead used for automotive battery production in the State of Pernambuco is obtained by the recycling of used batteries. After separation of the battery components, the metallic components are melted to obtain lead. The slag produced during the metallurgical process is about $36 \%$ by weight of feed material and is mainly composed of the chemical species $\mathrm{Fe}_{2} \mathrm{O}_{4}, \mathrm{Ca}_{3} \mathrm{SiO}_{5}, \mathrm{PbS}$, $\mathrm{FePb}_{4} \mathrm{Sb}_{6} \mathrm{~S}_{14}$ and $\mathrm{PbCl}_{2}$ (Morais, 2009).

The following main reaction occurs in the metallurgical process:

$$
2 \mathrm{PbSO}_{4}+\mathrm{Na}_{2} \mathrm{CO}_{3}+\mathrm{Fe}+9 \mathrm{C} \rightarrow 2 \mathrm{~Pb}+\mathrm{FeS} . \mathrm{Na}_{2} \mathrm{~S}+9 \mathrm{CO}+\mathrm{CO}_{2}
$$

The following secondary reactions

occur:

$$
\begin{gathered}
\mathrm{PbO}_{2}+\mathrm{C} \rightarrow \mathrm{CO}+\mathrm{PbO} \\
2 \mathrm{PbO}+\mathrm{C} \rightarrow \mathrm{CO}_{2}+2 \mathrm{~Pb} \\
\mathrm{PbSO}_{4}+2 \mathrm{C} \rightarrow \mathrm{PbS}+2 \mathrm{CO}_{2}
\end{gathered}
$$

The slag produced in the metallurgical process involves a jig stage that recovers part of the lead. However, a significant amount of lead, especially the fine fractions, remains in the jig tailing, which is stored, causing environmental impacts and serious risks to human health.

In a previous research, a concentrate containing $83.7 \% \mathrm{~Pb}$, was obtained from a sample with a grade of $15.2 \% \mathrm{~Pb}$, when utilizing a commercial amine as collector. This process, de-

veloped at UFPE, has been tested on pilot scale for expansion and industrial production. However, the results were not reproduced, due to the presence of fines resulting from imperfections in desliming operations at the pilot plant. The loss of amine efficiency in the presence of fines was observed in a previous research (Baltar, 1980).

In this research, the possibility of concentrating lead with a collector more tolerant to the presence of fines was verified with a sodium lauryl sulfate (SLS).

\section{Experimental phase}

The sample was collected in a decantation basin where the jig tail- ing is stored. In the basin, the slag is contaminated by sandy soil.

\section{Main equipment}

- Flotation Cell, Denver, Sub-A model.

- Zeta Meter System 3.0+, ZM3-DG, manufactured by Zeta Meter Inc.,

USA.

- RSV Tensiometer, Sigma-70, Finland. - Mechanical Mixer IKA, Eurostar,
SLS is a strong acid, very soluble in water, which can act as a collector in a wide $\mathrm{pH}$ range (Baltar, 2010). There is divergence with respect to the adsorption mechanism of organic sulfates in mineral surfaces. Quast (2000) quotes several authors who believe in physical adsorption based on results that indicate that the flotation of hematite $\left(\mathrm{Fe}_{2} \mathrm{O}_{3}\right)$ is only possible in areas with a positive charge. In turn, Mishra (1988) reported that organic sulfates form insoluble salts with several cations.

\section{Reagents}

The following reagents were used in the study: sodium lauryl sulfate (SLS) produced by SIGMA-ALDRICH, lead sulfate (VETEC), lead chloride (Riedel) with a computerized system to control the agitation speed, Germany.

- Scanning Electron Microscope (SEM).

\section{Characterization}

The sample was character- ized with respect to chemical composi-

and $\mathrm{NaOH}$ and $\mathrm{HCl}$ from Merck as $\mathrm{pH}$ regulators.

tion and particle size distribution. 


\section{Concentration Study}

Tests were performed to determine the zeta potential and the surface

\section{Results and Discussions}

The chemical analysis of a representative slag sample is shown in Table 1. Table 2 shows the $\mathrm{Pb}$ and $\mathrm{Fe}$ grades for each particle size range.

The results shown in Table 1 indicate a

Table 1

Main chemical compounds found in the sample studied.

Table 2

Particle size distribution and grades for each particle size range.

Figure 1

The slag sample appears contaminated with quartz. 150x400 mesh.

\section{Zeta Potential}

The zeta potential results are shown in Figure 2. The surface of the lead slag has an excess negative charge throughout the $\mathrm{pH}$ range studied. The contact

\section{Surface Tension}

Determining the surface tension of a solution is a safe means to monitor the residual surfactant concentration. The surface tension value of the liquid-gas interface decreases proportionally to the surfactant concentration in the solution. In tension in the presence of surfactant. The results indicated the most favorable condi-

considerable presence of silicates minerals in the sample, caused by soil contamination of the slag in the settling basin. Binocular microscopic analysis (Figure 1) confirmed the slag contamination. There was a

\begin{tabular}{c|c}
\hline Element & Grade (\%) \\
\hline $\mathrm{SiO}_{2}$ & 30.6 \\
\hline $\mathrm{Fe}_{2} \mathrm{O}_{3}$ & 24.5 \\
\hline $\mathrm{SO}_{3}$ & 14.2 \\
\hline $\mathrm{PbO}$ & 8.4 \\
\hline
\end{tabular}

high concentration of lead and iron in the finest fractions of the sample. This is due to the increased presence of silicates in the coarse fractions. tions for selective flotation. Based on these results, flotation tests were planned.

\begin{tabular}{c|c|c|c}
\hline \multirow{2}{*}{ Size, $\mathbf{m m}$} & \multirow{2}{*}{ Weight, \% } & \multicolumn{2}{|c}{ Grade, \% } \\
\cline { 3 - 4 } & & $\mathbf{P b}$ & $\mathrm{Fe}$ \\
\hline+0.21 & 69.7 & 9.9 & 11.2 \\
\hline $0.21 \times 0.15$ & 4.2 & 9.3 & 10.1 \\
\hline $0.15 \times 0.105$ & 5.0 & 9.4 & 13.0 \\
\hline $0.105 \times 0.037$ & 10.7 & 12.6 & 12.2 \\
\hline-0.037 & 10.4 & 14.4 & 15.2 \\
\hline
\end{tabular}

with SLS modified the original curve, indicating the presence of the collector on the surface of the lead particle. In the area with excess negative charge, the pres- ence of an anionic collector is possible only through specific adsorption, which shows the formation of a chemical compound (dodecyl sulfate lead) on the slag surface. this way, after contact with the solid, a possible increase in surface tension suggests that some of these molecules were "consumed" as a result of the adsorption on the solid surface. Figures 3 and 4 show the results obtained by determining the surface tension under different situations.

It was observed that the surface tension increases significantly in alkaline medium and that there is no influence of the conditioning time. However, at low $\mathrm{pH}$ values, the surface tension increases 
after 5 minutes conditioning. These results suggest that the alkaline medium is most favorable for collector adsorption and the slowest adsorption velocity was observed at low $\mathrm{pH}$ values.
Figure 4 shows that higher surface tension values were observed with conditioning in alkaline medium. In acid medium, there is a greater distance from the curves, representing the lead and
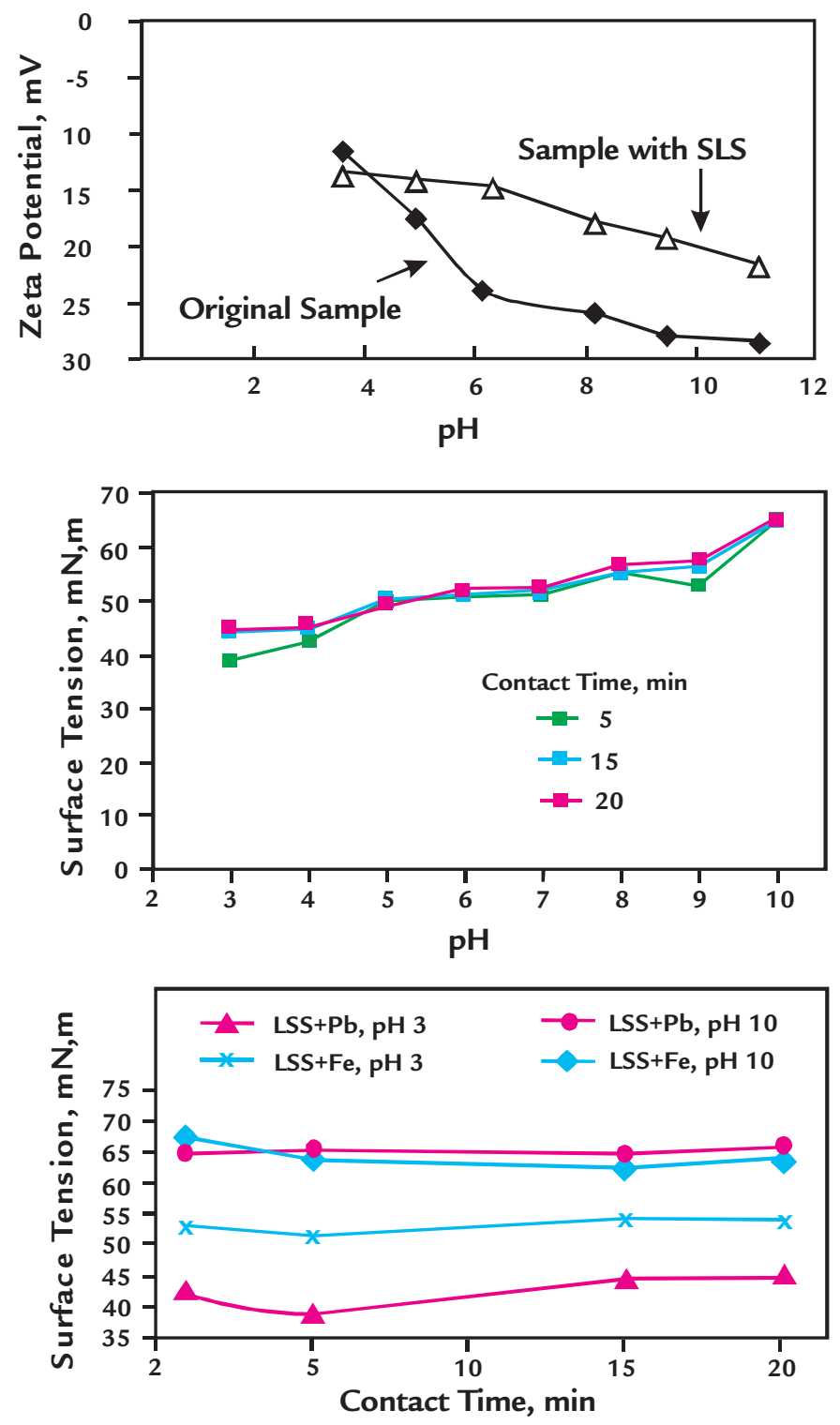

iron particles. These results confirm that the most favorable conditions for the SLS adsorption occur under alkaline conditions and that the selectivity is favored under acidic conditions.

Figure 2

Effect of $\mathrm{pH}$ on the zeta potential of lead particles before and after contact with SLS.

Figure 3

Effect of $\mathrm{pH}$ and contact time of the SLS with lead particles on the surface tension.

Figure 4

Effect of the contact time and $\mathrm{pH}$ on the surface tension of the SLS solution in the presence of $\mathrm{Pb}^{++}$and $\mathrm{Fe}^{+++}$.

with a $10^{-3} \mathrm{M}$ collector solution. concentration on the lead recovery at $\mathrm{pH}$

\begin{tabular}{c|c}
\hline Concentration (M) & Recovery (\%) \\
\hline $10^{-4}$ & 19.2 \\
\hline $5 \times 10^{-4}$ & 69.8 \\
\hline $10^{-3}$ & 79.0 \\
\hline
\end{tabular}

\section{Flotation}

Table 3 shows the effect of the SLS centration a recovery of $79 \%$ is possible

10. The recovery increases with the con-

Table 3

Effect of the SLS concentration on the lead recovery at $\mathrm{pH} 10$.

\section{Conclusions}

- The possibility of lead recovery from metallurgical slag by flotation using sodium lauryl sulfate was studied. The presence of quartz confirms slag contamination by soil.

- Pure lead slag showed a negative surface charge throughout the studied $\mathrm{pH}$ range. The zeta potential curves indicate adsorption of anionic collector on the lead slag in the presence of SLS. These results suggest an adsorption of chemical nature for SLS. 
- Surface tension results indicate that increasing $\mathrm{pH}$ values favor the lead lauryl sulphate formation. However, the same was observed with respect to formation of the iron lauryl sulfate.

\section{Acknowledgments}

The authors would like to thank the MOURA GROUP for the chemical analyses, geologist Luiz Carlos Bertolino from CETEM for the
- Flotation tests confirmed these evidences: (1) greater recovery was obtained at $\mathrm{pH} 10$ (79\% with only $10^{-3} \mathrm{M} \mathrm{SLS}$ ) and (2) poor selectivity was observed under alkaline conditions resulting in low grade concentrate. The most favorable conditions for selectivity were those observed in acid medium.

\section{Bibliography}

support with the mineralogical analyses, Prof. Antonio Eduardo Peres from UFMG for zeta potential determination, Mining engineering students Marcelo Pina and Lucas Augusto Coelho Ramos for supporting the implementation of the experimental stage and CAPES for the Master scholarship.

BALTAR, C.A.M. Aproveitamento de minério oxidado de zinco com baixo teor por flotação. Rio de Janeiro: COPPE, Universidade Federal do Rio de Janeiro, 1980. 226 p. (Dissertação de Mestrado em Engenharia Metalúrgica e de Materiais).

BALTAR, C.A.M.Flotação no tratamento de minérios. $2^{a}$ edição. Recife: Universidade Federal de Pernambuco, 2010. 234 p.

MISHRA, S.K. Anionic Collectors in Nonsulfide Mineral Flotation. In.: Reagents in mineral technology. SOMASUNDARAN, P., MOUDGIL, B.M. (editores). New York: Marcel Dekker, Inc., 1988. p.195-217.

MORAIS, A.G. Estudo da recuperação do chumbo proveniente de escória metalúrgica por flotação com lauril sulfato de sódio. Recife: Universidade Federal de Pernambuco, 2009. 62 p. (Dissertação de Mestrado em Engenharia Mineral).

QUAST, K.B. A review of hematite flotation using 12-carbon chain collectors'. Minerals Engineering, v. 13, n. 13, p. 1361-1376, 2000.

TEIXEIRA, J.A.A.B., SILVA, O.A. Chumbo. In.: DNPM, 2011. Sumário Mineral Brasileiro, p. 26-27.

Artigo recebido em 20 de agosto de 2012. Aprovado em 24 de outubro de 2012. 